\title{
Rural and Urban Areas Planning Orientation in the Flood Plain of the Mekong Delta, Vietnam
}

\author{
Nguyen Thanh Nguyen ${ }^{1}$ \\ ${ }^{1}$ People's Committee of Long An Province, Economic Department, Tan An, Long An, Vietnam \\ Correspondence: Nguyen Thanh Nguyen, People's Committee of Long An Province, Economic Department, 61 \\ Nguyen Hue street, Tan An, Long An, Vietnam. Tel: 84-72-3821694. E-mail: thanhnguyen@longan.gov.vn; \\ thanhnguyenla57@yahoo.com
}

Received: December 23, 2013 Accepted: January 13, 2014 Online Published: January 16, 2014

doi:10.5539/jsd.v7n1p94

URL: http://dx.doi.org/10.5539/jsd.v7n1p94

\begin{abstract}
This paper proposes new development orientation for cities and rural residential areas in the Plain of Reeds, a region in Southern Vietnam that is subject to annual flooding and is grounded in the author's practical experience and theoretical analysis. Furthermore, this study is based on the plain's features, the history of the foundation of regional urban and residential areas, and the successes and failures of previous planning in the region. Based on data from the Vietnamese government and the IMF, this development orientation is in opposition to the views of many leaders with respect to the development of the cities and rural residential areas of the region. It is hoped that this study will help administrators, planners, and other authorities in Vietnam and other countries.
\end{abstract}

Keywords: Plain of Reeds, Mekong Delta, Vietnam, rural residential area, urban; planning, orientation

\section{Introduction}

\subsection{Problem of Planning}

During the period of planned economies in Vietnam, all its rural and urban planning was developed and implemented by the government. Building a village or a city was a simple process because authorities simply decided on a settlement and used the national budget to build it. However, as Vietnam transitioned from a planned communist economy to a market-based economy, the planning of most socio-economic sectors must adapt; in a market economy, all planning must comply with both the rules of the new economy and with government regulations (Law on urban planning, No.30/2009/QH12). Over the past 20 years, urban and rural planning in Vietnam, particularly in the Mekong Delta, has witnessed many achievements, but there have also been a considerable number of mistakes made during planning and implementation. These shortcomings have constrained the feasibility of urban and rural planning projects in Southern Vietnam and in the Plain of Reeds, in particular, which is an agricultural flood region. Based on the results of this study, the author aims to reveal the infeasibility of such previous planning and its implementation and to propose a planning orientation for the sustainable development of urban and rural areas in the region.

\subsection{Presentation of the Plain of Reeds}

The Plain of Reeds (or Dong Thap Muoi Plain) is an area situated in the Mekong Delta of Southern Vietnam; its territory belongs to Long An, Tien Giang, and Dong Thap provinces and measures approximately $4,000 \mathrm{~km}^{2}$ (see Figure 1). This region was the base of the Liberation Army during the Vietnam War. In 2012, the population in the Plain of Reeds was approximately 1.5 million, most of whom are ethnic Kinh. More than $75 \%$ of the populations are farmers who live in the countryside. The region's economy features industrial (20\%), agricultural (60\%), and service (20\%) sectors, and the GDP has reached USD \$1,000 per capita. Development of the Plain of Reeds began in late 1970 s; by the 1980 s, only $20 \%$ of the plain had been developed, however. The plain now produces a substantial portion of Vietnam's grain.

The Plain of Reeds is a wet land area with its own ecological system and annual flooding that lasts between two and three months. In large flood years, the average water level can reach up to three to four meters above the surface fields. The area's terrain is flat, low $(+0.5-+1.0)$, and rises in the direction of Cambodia. It is new alluvia land that has many rivers and canals; therefore, its natural conditions hinder infrastructure construction. Building 
roads, bridges, and houses is expensive because of the weak soil and low land. With the exception of a few cities built during the French colonial period (which were marked by simple planning), older cities, towns, and residential areas in the region were not planned. During the 1990s, the government prepared a master plan for the area that included socioeconomic planning. Many new cities and residential areas were planned, and these plans have been executed over the past 20 years. This planning has resulted in a number of successes and failures for planners and the government. After analyzing these planning results, such as subsequent socioeconomic development and migration trends, this paper ultimately proposes a new planning orientation for the future.

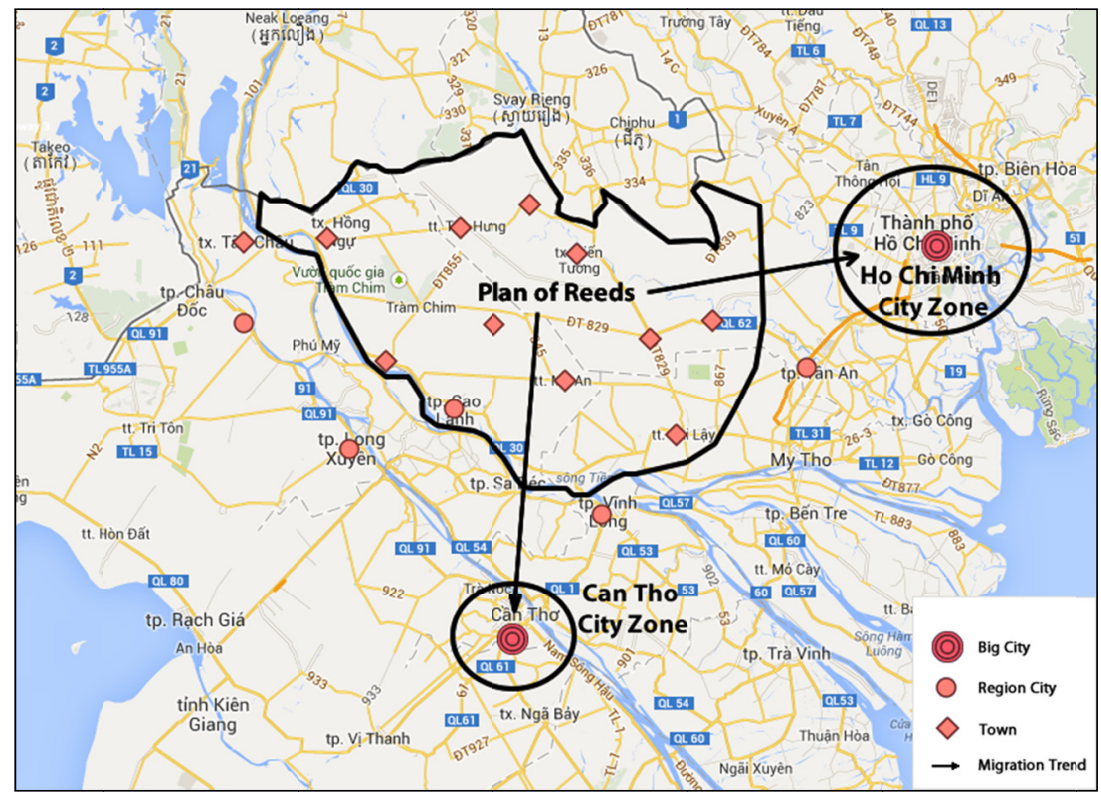

Figure 1. The Plain of Reeds' position and recent urban system

Source: UN and IMF.

\subsection{Historical Context of Rural Residential Areas and Cities in the Plain of Reeds}

Southern Vietnam, including the Plain of Reeds, has a history that stretches back approximately 300 years. An influx of Viet people from the central and northern areas of Vietnam immigrated to this new land 100 years ago. They arrived mainly by waterway, infiltrating the Plain of Reeds along its rivers (the Waico and Mekong Rivers) and natural streams to reclaim the desert land for rice planting. Inhabitants lived along the rivers in residential areas near to and supported by the agriculture and fishery industries. Residential lines (a type of residential area where constructions are built along a line) were gradually founded along the rivers, and a few residential clusters (residential quarter in countryside) also appeared later at Thu Thua, Tan An, Ben Luc, Cai Lay, and Cao Lanh that included the development of a small level of commerce.

During the French colonial period, the government built some infrastructure to exploit the Plain, which attracted settlers to the region; many residential lines developed along canals and roads at this time. Residential clusters grew to become precursors to towns such as Moc Hoa, Cai Lay, and Cao Lanh.

During the Vietnam-American War (1954-1975), many towns were established that became the centers of provinces, districts, and communes. The government also founded residential clusters to concentrate the population in "strategic hamlets" or "populous areas" for purposes of war; of course, these types of towns had extremely poor infrastructure. In liberation areas, inhabitants lived in a dispersed manner for safety reasons.

In 1975, the government began promulgating policies to exploit the Plain of Reeds. Both the central and provincial authorities invested in a large system of canals associated with rural roads (more than 5,000 km of canals and 3,000 km of roads). Residents from other provinces immigrated to the plain region to convert its virgin soil into approximately 350,000 hectares of rice fields. During this time, new residential lines were established. Additionally, habitat clusters in communes, 'flood-safe' clusters, towns, cities, and commerce clusters appeared as centers of trade and service. Older towns were upgraded and all towns contributed to the 
emerging picture of the residential system. Lines, towns, and cities in the region are reasonably connected to one another and this process has established a habitat that differs from residential systems in other regions.

The Plain of Reeds belongs to three provinces and there is not a common authority of the Plain. Each province has its own power for planning and although the provincial authorities declared that they cooperated together in planning but it seems this is not true in reality. The Decision of Prime Minister (No.939/2012) decided that the spatial and urban planning in Plain of Reeds must comply with master plan of Mekong Delta region. However, in recent years there were also the plans that appeared with the subjective viewpoint of provincial leaders. This is a big obstacle for the planning in the Plain of Reeds.

\subsection{Literature Review}

Planning an area (district, province, or region) must be based on the high-level master plans for the planning territory. The Plain of Reeds is considered a small region in the Mekong Delta, and the development orientation of this region depends on planning in the Delta region. Moreover, this planning is affected by other nearby planning, such as the Important Economic Zone of Southern Vietnam and the Frontier Areas Plan of Cambodia. The orientation of the region's socio-economic planning was formulated during the last decade, as Vietnam further integrated itself into a market economy, and there were many failures in development and investment. The government issued regulatory documents to direct planning, including the Law of Construction in 2003, the Law on Urban Planning in 2009,the decision approving the Adjustment of the Master Plan Orientation for Vietnamese Urban Development up to 2025 with a vision toward 2050 (Decision 445/QĐ-TTg-2009), the decision to approve the Master Plan of Socio-economic Development of the Mekong River Delta up to 2020 (Decision 939/QD-TTg-2012), and the decisions on planning the Ho Chi Minh city region and Mekong Delta up to 2025 and vision up to 2050 (Decision 589/QĐ-TTg-2008; 1581/QĐ-TTg-2009). Planning must comply with these lawful regulations with respect to general development and investment in the country.

Many planners have concluded that rural and urban development planning must be integrated (Ion DANCI, 2010) because towns and the countryside are interdependent (Clayton et al., 2000; Armstrong et al., 1986). Rural and urban areas are intricately related (Mylott, 2009) and the development of both must be considered when planning an area (Zhang \& Wang, 2012).

In rural and urban planning, planners must refer to the socio-economic master plan, including the migration trends of the population, in particular. In certain developed countries, there is a tendency for urban populations to move to ex-urban fringes; the government must plan for this development and invest in infrastructure for rural inhabitants (Armstrong et al., 1986). Depending on the socio-economic characteristics of an era, there have been shifts in migration direction with respect to metropolitan and non-metropolitan areas (Mylott, 2009). However, most developing countries are characterized by having more economic opportunities in cities which results in a substantial migration flow from the countryside into rural areas, (Aworemi et al., 2011; Herrmann \& Svarin, 2009). This trend is an important basis for rural and urban planning.

One of the most important bases for planning is estimating population growth. The accuracy of this estimation often determines the quality of planning. Previous Decisions of the Vietnamese government speculated that the population of the Mekong Delta (in which the Plain of Reeds is a small region) would substantially increase (Decision 1581/QD-TTg, 2008), but updated estimations predict that population growth in the Mekong Delta may be slower and that migration may flow from rural to urban areas (Decision 939/QD-TTg, 2012). Concurrently, the number of inhabitants in urban areas, particularly in the region of Ho Chi Minh City, is predicted to increase substantially (Decision 589/QD-TTg, 2008; Decision 445/QD-TTg, 2009). In Decision 1581, the government confirms that the Plain of Reeds is an agricultural and controlled flooding area. The government has thus oriented planning to exploit eco-tourism and inter-frontier development of the Plain and areas near Cambodia. According to moderate UN and IMF projections for Vietnam, the population of the Mekong Delta is predicted to increase slowly until 2015 and then decrease substantially from 2015 to 2050 . In 2100 , its population is expected to be half that of 2015. There are also scenarios predicted for the region's socio-economic growth in which population, urbanization, GDP, and the industrial sector may continue to develop strongly until 2050; in fact, this remains the basis for current projections in the master plan for the Mekong Delta. However, these scenarios are not realistic, particularly because existing governmental policies are not formulated to facilitate the development of industry and commerce in this region. Instead, current governmental policies aim to develop the Mekong Delta as an agricultural region.

\section{Methodology}

For this study, the author collected regional information related to governmental socio-economic planning and data related to the region's economic development, population growth, migration trends, the formation and 
development of rural and urban areas from the General Statistics Office, provincial statistical offices, UN and IMF reports, and other government documents. The author also collected accounts related to planning and implementing development plans in the urban and rural areas of the Mekong Delta and the Plain of Reeds over the last 20 years and lessons of other transition countries related to building urban, rural, and economic zones. Based on data analyses, the author presents a realistic vision for the future that can be the basis for urban and rural planning.

\section{Development of Cities and Residential Areas in the Plain of Reeds}

\subsection{Experiences of Residential Planning}

Prior attempts at planning cities and residential areas in the Plain of Reeds have met with both success and failure.

The development strategy of any region must be based on its socio-economic master plan. The feasibility of city and residential area planning depends on the quality of such planning. The master plans of the Plain of Reeds changed considerably over a short period of time: there was a period in which the government preferred to build every district into an industrial-agricultural area. These planning ideas, however, were not feasible and represent serious mistakes in planning. Recently, the Vietnamese government redesigned its vision for the Mekong Delta and the Plain of Reeds; they now consider this region to be an agricultural area, the industrial and service sectors have taken on a support role for agriculture.

The planning strategy for cities and residential areas has been based in the past on the population development policies of the government. After the Vietnam-American War (1975), the government issued a policy of the 'new economy', and thousands of urban inhabitants were forced to settle in the desert land of the Plain of Reeds. The plan was a failure; after five years, most of these people had escaped from the flood area because they were not farmers and the infrastructure was poorly developed. In the mid-1980s, the government developed another migration plan with the farmers of other provinces who participated in breaking fresh ground of the Plain. The area's population grew quickly and the new inhabitants settled mainly in the countryside, although a small number were settled in small towns. This migration plan was successful until the end of the 2000s, when the population of the Plain region began to decline. Thus, this residential planning policy mainly served to develop agriculture in the region.

The practices of an area's inhabitants are an important factor to consider in residential planning. The inhabitants of the Plain region are accustomed to living in residential lines because this type of settlement is convenient for agricultural production and comports with their lifestyles and traditions. Additionally, residential clusters seem to be adapted to people who are salary earners or work in the service sector Conversely, the implementation of an inappropriate residential settlement can lead to failure. An example is the 'flood-free cluster' program implemented by the government, which was unsuccessful because it did not easily fit with inhabitants' lifestyles (see Table 1). There were also impractical residential areas built based on the subjective ideas of authorities and included townships, industrial communes, and economic border areas.

Governmental authorities' opinions are also important. In Vietnam, planners must often consider the viewpoint of government leaders in their planning. These views are typically subjective, not based on scientific analysis, and frequently lead to failure. Recently, there have also been provincial plans that aim to industrialize and urbanize the Plain of Reeds.

The lesson of planning in centralized economy is the unsuitable orientation for spatial planning of area; this caused the imbalance between rural and urban areas, lack of service and industry sectors for region. Other mistake of planners is their false conjecture of rural and urban development and the resources, it leads to bad infrastructure construction and abandoned residential plans.

The lack of a common management of planning is a severe governmental mistake. Actually, each province in Plain of Reeds has its own power and ideas about spatial planning. This causes disconnection of urban and regional infrastructure systems and the contradiction in exploiting Plain. The decentralization of planning is a barrier for the development of rural and urban areas, especially for the formation of central cities of region.

\subsection{Application Styles of Residential Areas and Cities in Plain of Reeds}

The models of cities and residential areas that are applied in the Plain of Reeds are residential lines that associate with clusters, urban centers, and cities. The new settlement system has urban and rural areas that develop completely; the traditional system has not central cities, less developed towns and residential lines or clusters (see Figure 2). 


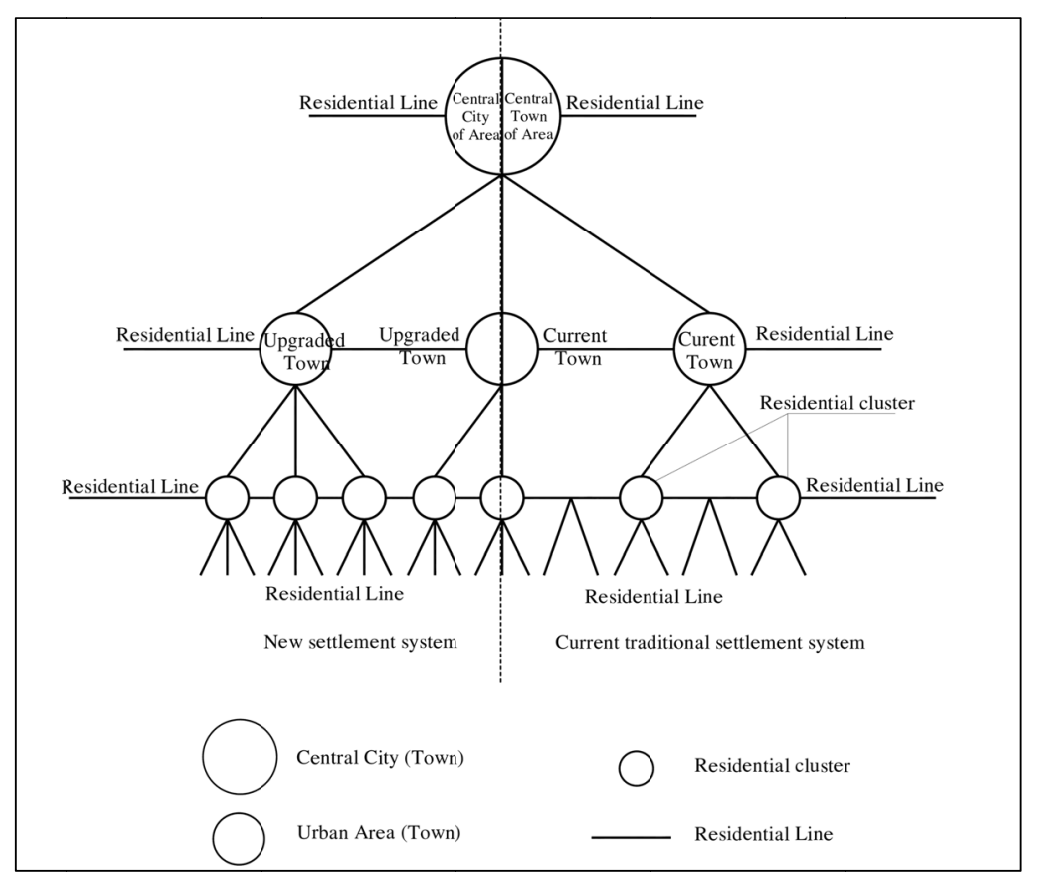

Figure 2. Organization models of rural and urban areas (current and proposal system)

\subsubsection{Residential Lines}

Residential lines were typically established along rivers, canals, and/or roads and were based on the traditional practices of inhabitants. For old residential lines, urban planning reasonably rearranges houses and plans infrastructure and construction to improve social welfare. In the past 20 years, the government has built a system of canals that helps provide irrigation and drainage for agricultural production; the canals are also convenient for transporting goods. The soil excavated from the canals was used to build roads and foundations for homes along the canals. These roads also act as dikes to protect crops from early flooding, which allows farmers to harvest their rice. When flooding slows, these dike systems help pump flood water out of fields to allow new crops to be planted. Inhabitants in such residential lines may have land around their houses to plant vegetables or raise chickens and ducks, as is typical with households in the Vietnamese countryside. Infrastructure including water supply, electricity, and telephone cables is built along the road systems. Construction that provides services and that benefits social welfare, such as schools, hospitals, entertainment, markets, and governmental offices, are placed at the centers of villages or towns such that inhabitants can easily reach them. This type of residential planning was successful and became the core type of development in the Plain of Reeds because it is comfortable for the practices, livelihood, and production modes of its inhabitants. Farmers can tend to their rice fields more easily and receive additional income from their fish ponds or vegetable gardens; their habitat is adapted to their traditions. However, the shortcoming of this residential plan is that the cost of infrastructure construction is high, particularly regarding water supply, electricity, welfare and road systems (see Figure 3).

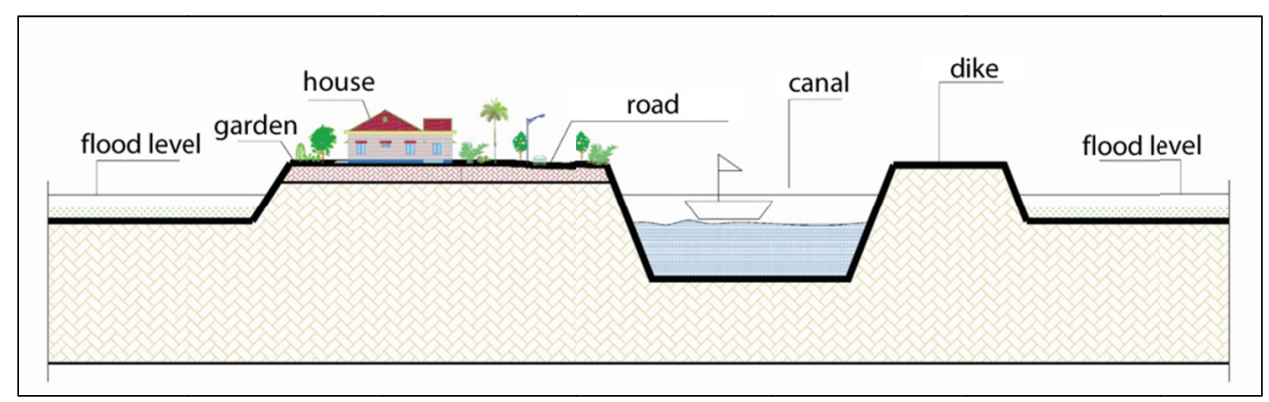

Figure 3. Residential lines 


\subsubsection{Residential Clusters}

Residential clusters were typically arranged surrounding a chief place of communes or near suitable positions for trade. Houses are arranged as they would be in a town or city, although with less infrastructure and welfare construction. In the Plain of Reeds, there are two types of residential clusters: clusters with raised land levels and clusters with dike systems to protect against flooding. These clusters are typically built at the intersection of rivers, canals or main roads. The most popular cluster type is the first, which is built by raising the land's altitude, and all construction is built on the artificially high land. This type of residential cluster is costly to construct, but it is safe and allows for easy drainage during the flood season (see Figure 4).The dike style cluster is built in an area that is surrounded-and thus protected-by the dike system. This type of residential cluster can reduce building costs because it does not require large soil volumes to raise the land level (see Figure 4) but does require regular maintenance and drainage pumping during the flood season. Thus, this residential cluster type is inexpensive in terms of infrastructure construction and is suitable for non-agriculture workers, such as businessmen, officials, and salary-earners, but it is not appropriate for the customs, livelihoods, and production practices of farmers, which explains the failure of the "flood-safe residential clusters" implemented by the government. After severe floods in 2000-2002, many new residential clusters were built to supply homes for inhabitants of the Plain with the financial support of the government, but the program was not successful and attracted few farmers (see Table 1) because of the lack of infrastructure and inappropriate decisions about positioning the planning areas, particularly the residential clusters that were not acceptable by farmers. Surveys show that those who accept living in these clusters are the poor who have no land for agricultural production or settlement typically the unemployed or daily wage-earners. Most farmers in the region have gradually raised the land level of their own houses to be higher than the highest flood level, and they like to live in residential lines.

The population of residential lines and clusters account for $80 \%$ of the Plain's inhabitants, but statisticians have recorded a downward trend in population over the past five years; data of statistic office showed a similar population growth rate in two main provinces of Plain because there are a migration trend from region to big cities (see Table 2). Young people are migrating from the Plain of Reeds to Ho Chi Minh City and the Southern Important Economic Zone of Southern Vietnam.

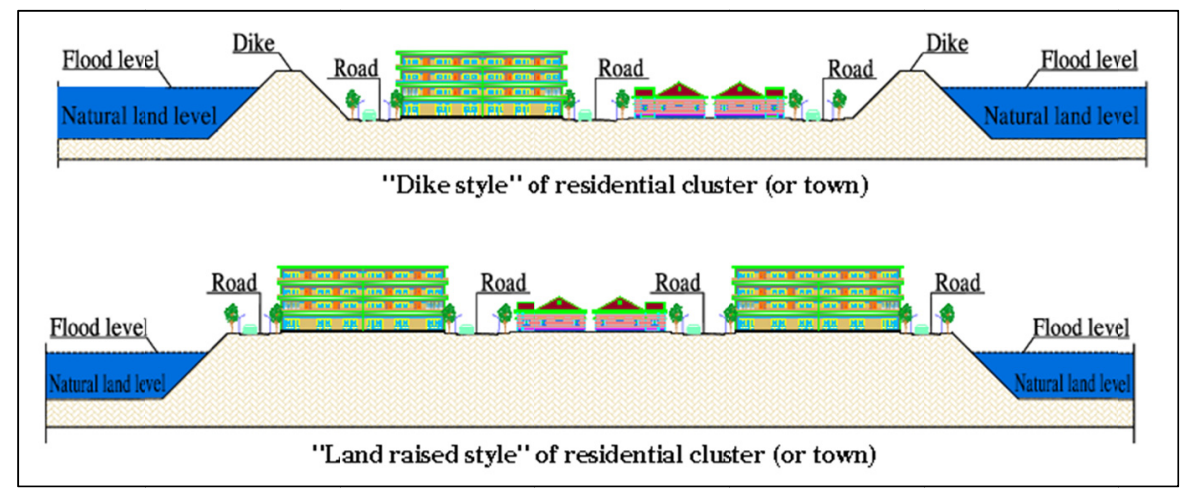

Figure 4. Residential clusters

Table 1. Population in 'flood-safe clusters' ten years after construction

\begin{tabular}{ccccc}
\hline Province & Planned land lots & Settled households & Non-farmers households & Farmers households \\
\hline Long & 32,930 & 16,470 & 13,196 & 3,274 \\
An & $(100 \%)$ & $(50.01 \%)$ & $(40 \%)$ & $(10.01 \%)$ \\
Dong & 47,270 & 34,938 & 28,666 & 6,272 \\
Thap & $(100 \%)$ & $(73.91)$ & $(60.64 \%)$ & $(13.27 \%)$ \\
\hline
\end{tabular}

Source: Construction offices of Dong Thap and Long An province. 
Table 2. Population growth rate of the Plain of Reeds (previous year $=100 \%$ )

\begin{tabular}{ccccccc}
\hline \multirow{2}{*}{ Year } & \multicolumn{3}{c}{ Dong Thap Province } & \multicolumn{3}{c}{ Long An Province } \\
\cline { 2 - 7 } & total & urban & rural & total & urban & rural \\
\hline 2000 & 100.70 & 101.48 & 100.56 & 101.37 & 102.87 & 101.08 \\
2005 & 100.79 & 102.66 & 100.45 & 100.81 & 101.57 & 100.66 \\
2006 & 101.05 & 102.30 & 100.81 & 100.85 & 101.60 & 100.69 \\
2007 & 100.11 & 102.33 & 99.67 & 100.91 & 101.66 & 100.75 \\
2008 & 100.24 & 102.34 & 99.82 & 100.73 & 101.48 & 100.57 \\
2009 & 100.16 & 102.17 & 99.75 & 100.56 & 101.32 & 100.41 \\
2010 & 100.33 & 103.19 & 99.73 & 100.46 & 101.56 & 100.27 \\
2011 & 100.16 & 100.17 & 100.16 & 100.49 & 100.36 & 100.31 \\
2012 & 100.19 & 100.20 & 100.18 & 100.57 & 100.86 & 100.51
\end{tabular}

Source: General statistic offices, Vietnam, 2013.

\subsubsection{Towns and Cities}

Towns and cities are developed from residential clusters by adding additional infrastructure and social welfare investments and typically assume the role of the head location of a district or region. Urban areas that are in flood plains have mainly employed the raised-land method to protect against flood; this solution costs more as an initial investment but is easier to manage. The dike method is also used, but it is not as popular because of its complicated and costly management. Urban centers in the Plain of Reeds are primarily "grade five" (Decree No 42/ND-CP-2009) and function as administrative, cultural, educational-training, service, and economic centers. These urban centers play the important role of promoting socio-economic development of the communes or districts. The population of an urban center is typically 5,000 to 10,000, with non-agricultural labor of over $65 \%$. There are few "grade four" cities in the Plain of Reeds, and those that do exist are the head locations of provinces (Cao Lanh) or the main centers of the region (such as Moc Hoa, Hong Ngu, Sa Dec, and Cai Lay). Their infrastructure was built well to contribute to their roles as centers for development. A particular trait of urban centers is that their population who practice agriculture is comparatively high (30-35\%), so there is the mixture of urban and rural life in urban areas. The industrial sector is weak and has developed slowly, which has shaped towns and cities as mainly service and administrative centers. In the past ten years, the population of urban areas has grown slowly and is predicted to decline in the near future (see Tables 2, 3).

\subsection{Development Orientation of Urban and Rural Residential Areas in the Plain of Reeds}

\subsubsection{Basis of Orientation}

The most important basis for the planning of urban and rural residential areas in the Plain of Reeds is the government plan that decides the development of regions. The Prime Minister issued Decision No. 939/QD-TTg for this flood region, which included the decision of "approving the overall plan on socio-economic development of the Mekong River Delta up to 2020". In this plan, the government determined that the Plain of Reeds will be a region of agriculture and ecology, and it does not belong to the important urban and industrial zones of the Mekong Delta (the main urban centers of the Mekong Delta are situated in Can Tho, My Tho and Ca Mau). The development of urban centers and rural residential areas must adapt to this socio-economic development orientation. Through this decision, industrial and service sectors serve mainly as support for agriculture, and it seems that industrialization in the Plain of Reeds will be difficult. The development of urban and residential areas may be hindered by weak governmental investment and unattractive locations for private investment.

The second basis for planning is the real trend of economic development. In reality, if a country or region has an economy based only in agriculture, its economic growth is always low, and both rural and urban areas are difficult to develop. The Mekong Delta and particularly the Plain of Reeds is an agricultural region. Its economy seemed to develop quickly over the past 20 years; the income of inhabitants rose from USD \$500 (2000) to USD $\$ 1,200$ (2012) per capita (year). Now, however, the desert land is almost fully exploited; rice productivity has achieved one of the highest rates of production in Asia, but the income of farmers over the past five years has been sluggish. Agricultural growth has peaked and is beginning to decline. Farmers' income is slumping because of low prices in the rice market and the small rice fields allotted to each household (approximately 1.5 hectare 
per household). Moreover, the agricultural mechanization program of the government has proven successful, and farmers now use machines in almost every step of farming. Therefore, the need for labor in paddy planting has dropped, and workers have found it difficult to secure a job in rural areas. One of the special aquaculture products of the region is the Basa catfish, an important source of income for farmers since 2000. However, in the last five years, trade barriers with the US have caused serious drops in the price of this fish; many farmers went bankrupt, and the future of aquaculture now appears dark. Although there are a few industrial parks and food-processing enterprises that were built in the region, they are too small to stimulate economic development or to recruit more labor to the Plain. Additionally, government policies limit land use being transferred from agricultural purposes to other purposes. Some have tried to develop tourism as a driver of the economy, but it has been unsuccessful and shows a lack of potential. Other leaders have proposed building frontier economic zones near the Cambodia-Vietnam border with the hope that they can encourage investment and promote trade between the two countries. Two main zones (Dinh Ba, Binh Hiep) and many small frontier commerce areas have been established, but the results have been disappointing because of political instability in Cambodia and the poor potential of the plans. Although the government has attempted to invest in basic construction, poor infrastructure has hindered the Plain's development. The combination of all these economic obstacles hinders the growth of the urban and rural residential areas in the Plain of Reeds. The statistics on GDP and agricultural production growth of Dong Thap and Long An provinces (the two main provinces of Plain) demonstrates the slow downtrend of the economy (see Figure 5).This sluggishness of the agricultural economy is a barrier to the development of urban and rural areas.

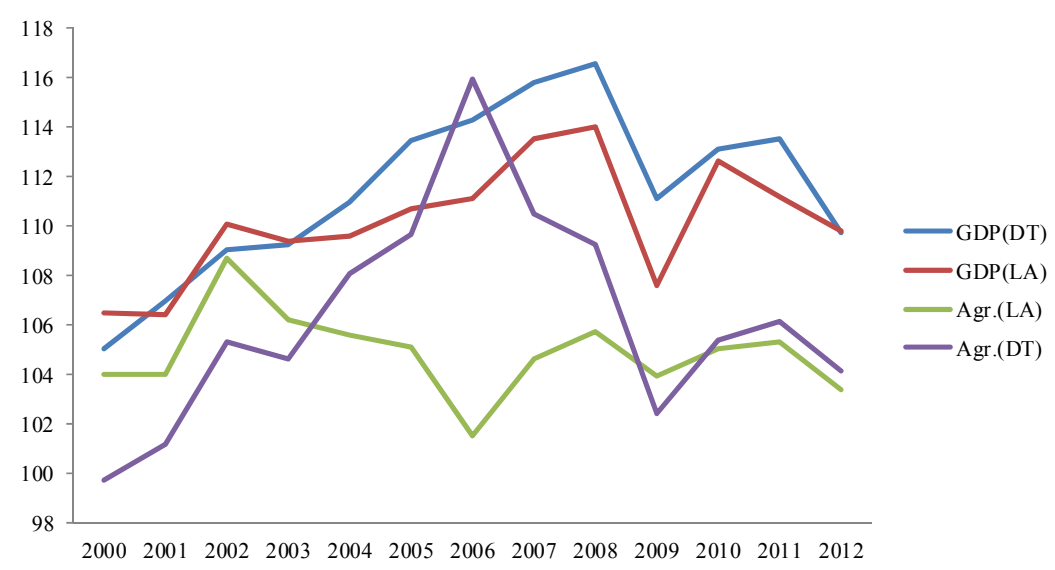

Figure 5. GDP and agricultural growth of long An (LA) and Dong Thap (DT) provinces (previous year= 100\%)

Source: General Statistics office, Vietnam, 2013.

Migration trends also comprise an important basis for residential planning. There has been migration flow from the countryside to urban areas in most countries of the world; some countries have issued policies to combat this trend because of overloaded urban infrastructures. To keep the countryside population in place, the Chinese government has attempted to implement many plans: new townships, programs such as "leaving agriculture but not leaving the countryside", and new rural villages. These plans achieved some positive results, but they cannot prevent the migration from rural areas to big cities and industrial zones. In the 1990s, the Vietnamese government conducted a large migration into the Plain of Reeds to better exploit its land. The population of the region increased rapidly, and many new residential areas and towns were established. However, by the end of the 2000s, the trend had reversed: the young laborers of the Plain now tend to work in big cities (Can Tho, Ho Chi Minh City, etc.) and industrial zones after graduation, even if they are manual laborers. This is because they can earn more money in cities than working in the Plain of Reeds, and they have the chance to enjoy the welfare of cities. The government has implemented many programs and policies to discourage migration and reduce the overloading of big cities but has achieved only minimal results. A recent report of the Vietnamese government demonstrated that the migration population has grown quickly and accounts for $5 \%$ of the total population in 2013. Police data show that approximately $7-8 \%$ of laborers from the Plain work in Ho Chi Minh City, but they continue to register as inhabitants of the Plain of Reeds. According to UN and IMF projections, if the moderate socio-economic scenarios of the Mekong Delta occur (high possibility for the Plain of Reeds), the population of 
the area will mostly migrate to big cities, particularly to the Ho Chi Minh City zone because of the prospects of a better life (see Table 3). This must be considered carefully during planning.

Table 3. Characteristics of high and medium socio-economic scenarios of the Mekong Delta

\begin{tabular}{ccccccc}
\hline & \multicolumn{3}{c}{ Moderate scenarios } & \multicolumn{3}{c}{ High scenarios } \\
\cline { 2 - 6 } & 2025 & 2050 & 2100 & 2025 & 2050 & 2100 \\
\hline Population & 18 million & 15 million & $7-8$ million & 20 million & 30 million & 40 million \\
Urbanization & $28 \%$ & $30 \%$ & $<40 \%$ & $36 \%$ & $45 \%$ & $>60 \%$ \\
GDP growth & $2-3 \%$ & $<2 \%$ & & $4-6 \%$ & $>4 \%$ & \\
$\%$ share Industrial sector & $20-25 \%$ & $<30 \%$ & & $35-40 \%$ & $>40 \%$ \\
\hline
\end{tabular}

Source: UN and IMF projections for Vietnam.

\subsubsection{Proposal Orientation}

Based on the above data, the prior experiences of planners, and the customs and habits of the population, the author proposes a new orientation for the development of urban centers and rural residential areas in the Plain of Reeds.

The successes and failures of residential planning over the most recent 20 years reaffirm the accepted model that residential lines are the basis of inhabitant disposition; residential clusters act as the service and administrative centers. There must be harmonious development between lines and clusters that is based on the growth of agriculture, services, and industry. The approved master plan of the region confirms that the Plain of Reeds is an agricultural area, which indicates that the development of urban centers and industrial zones will be constrained. Cities and towns will undertake administrative and service roles. The most efficient model will apply the 'raised land level' method and keeps a harmonious association between infrastructure for residential areas and agricultural production.

In the near future (to 2020), international experts predict that the population of the region may grow slowly and begin to decline later in this decade (2010s). During this period, the infrastructure of residential lines and clusters such as roads, electricity, water supply, and construction to benefit welfare and provide services may be improved to raise the quality of life of the population. These infrastructure systems might be built and ameliorate by the "new rural areas" program of the Vietnamese government. This planning orientation encourages the government not to plan additional new lines or clusters but instead to concentrate on reinforcing and enhancing the "flood-safe clusters and lines" that continue to have many vacant plots of land. Regarding older residential areas, they can also reorganize approximately $30 \%$ of these areas of the Plain for new households. In addition to Cao Lanh (the capital of Dong Thap province), three towns Moc Hoa, My An, Hong Ngu will be upgraded to cities, and these central urban areas will have the service, administration, and industrial functions. The population of each city is approximately 50,000. The other towns can be enlarged $10 \%$ to $20 \%$ (the population of each town is estimated at approximately 5,000 to 10,000) to satisfy population development. By 2025, it is estimated that two provincial cities will be 'grade two' (Tan An \& Cao Lanh), approximately 50\% of district towns will become ' grade three' and 30\% of village towns will be 'grade four'(Vietnamese standard).

Over the long term (up to 2050), the population of the Plain of Reeds may decline significantly. The government will concentrate on improving the infrastructure and on the construction of projects to improve the welfare of towns and rural residential areas. Although cities, towns, clusters, and residential lines will have fully completed infrastructure, laborers may continue to be attracted to the cities of the Important Economic Zone of Southern Vietnam and the urban centers of the Mekong Delta. Residential clusters and lines might stop developing, and some houses in remote rural (and urban) areas may be abandoned. However, some rural areas near the Important Economic Zone with accessible transportation (National Road 1, 62, N1, N2, and Highway) may be developed as accommodations for urban workers. Cities in the Plain of Reeds may serve only as service and administrative centers, whereas cities in the Important Economic Zone of Southern Vietnam may become highly developed and attract inhabitants from the Plain of Reeds and other nearby provinces. The differences in future plans and the plans of the past are the harmonious connection of rural and urban areas, the developed infrastructure in cities, towns and rural residential lines and clusters (see Figure 6). 
The Plain of Reeds is a special ecological region; its fertility land is maintained by alluvia from flood so the development of residential areas and other infrastructural constructions should not prevent the 'benefit' of flood. The planners have to be careful to preserve region ecology in their planning. Besides, administrators may reserve reasonable land for future development.

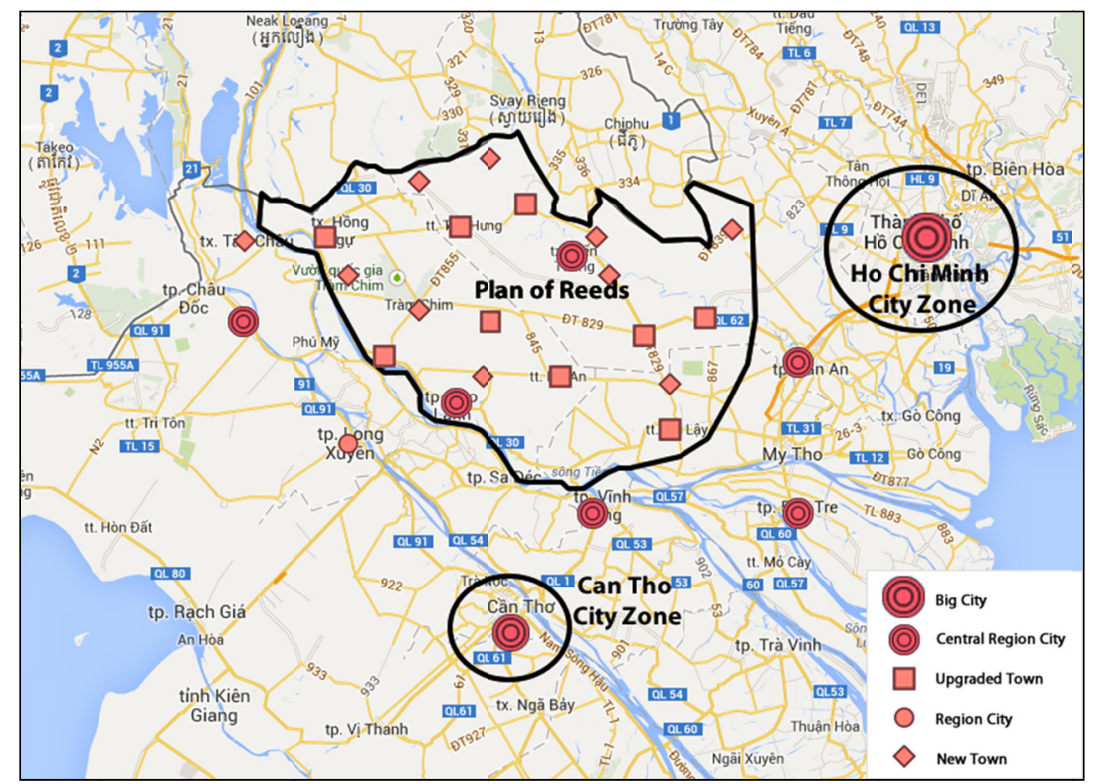

Figure 6. Future urban system of Plain of Reeds (proposal)

\section{Conclusion}

The planning of an area is always an estimation of the future. The development orientation of a residential area or city is valuable and relevant if it is based on socio-economic planning that accurately predicts the development of a region. Previously, the Plain of Reeds did not have a master plan that could be used as a guide for its development. In 2010, the central government improved the socio-economic plans of the Mekong Delta, the Important Economic Zone of Southern Vietnam and Provinces of the Plain of Reeds. These master plans determine that the Plain of Reeds will be an agricultural zone of the country. Because of this and because of the region's geographical disadvantages, the cities of the Plain will develop modestly. Urban and rural inhabitants of this area will decline in number in conjunction with the industrial development and urbanization of the Important Economic Zone of Southern Vietnam. Therefore, the development orientation of urban and residential areas must account for this prediction, particularly given that Vietnam is building a market economy.

The economic development situation is the important basis for the planning. If service and industrial sectors growth strongly, the urban areas may also develop. It is difficult for an agricultural region to maintain high growth rate when it has reached the peak of productivity and there is no deserted land. Actually, the plain of Reeds has fallen into this situation, the sluggishness of an agricultural economy causes migration flow from Plain to other attractive economic zones where people can earn more money. This hinders the development of urban and rural plans in the region.

The Plain of Reeds is a very special ecological region of Vietnam; it is a wet land area with high level of biodiversity. The alluvia from flood create the soil fertility of Plain so administrators have to maintain this precious resource. In previous planning, the local authorities decided wrong plans that impact to the sustainable development of Plain. One of experiences is the construction of dike system to protect absolutely residential lines against flood that obstructs dangerously water flow. Therefore, all the planning in region has to be appraised and controlled thoroughly about environment and ecology protection.

Previously, some cities and rural residential areas have been planned with the subjective and shortsighted ideas of both leaders and planners, and these plans were not feasible. In planning, subjectivity and conservatism are frequently the reasons for failure. Planners must revise their planning if there are changes in the socio-economic or development conditions of the planning area. In the coming 10-20 years, it will be difficult for urbanization to advance if there are no special breakthroughs in the socio-economic development of the Plain of Reeds. 
Finally, administrative system of Plain is a severe problem; the government should establish a powerful regional management system that can decide all plans in Plain of Reeds. If not, the future planning of urban and rural areas will be difficult to satisfy the real development of this special Plain.

\section{References}

Armstrong, J. H., Gross, M., Mullin, J. R., \& Yaro, R. D. (1986). Infrastructure planning in rural Massachusetts. Landscape Architecture and Regional Planning, Faculty publication series, University of MassachusettsAmherst. Retrieved from http://scholarworks.umass.edu/larp_faculty_pubs/

Aworemi, R. J., Azeek, A., Adegoke, I., \& Opoola, N. A. (2011). An appraisal of the factors influencing ruralurban migration in some selected local government areas of Lagos State Nigeria. Journal of Sustainable Development, 4(3), 136-141. http://dx.doi.org/10.5539/jsd.v4n3p136

Clayton, B. D., Dent, D., \& Dubois, O. (2000). Rural planning in the developing world with a special focus on natural resources: lessons learned and potential contributions to sustainable livelihoods- an overview. International Institute for Environment and Development-Environment planning issues, No 20, December 2010. Retrieved from http://pubs.iied.org/7828IIED.html

General Statistics Office. (2013). Statistical Yearbook of Vietnam 2012. Statistical publishing house, Hanoi, 2013.

Herrmann, M., \& Svarin, D. (2009). Environmental pressure and rural- urban migration: The case of Bangladesh. MPRA Paper, No 12879, posted 20-Jan-2009. Retrieved from http://mpra.ub.uni-muenchen.de/12879

Ion DANCI. (2010). The importance of plans in rural land planning. Journal of Settlement and Spatial Planning, 1(2), 129-134. Retrieved from http://geografie.ubbcluj.ro/ccau/jssp/arhiva2_2010/05JSSP022010.pdf

Mylott, E. (2009). Urban- Rural Connections: A Review of Literature. Scholars-Archive@OSU, Papers (RuralUrban Connections). Retrieved from http://ir.library.oregonstate.edu/xmlui/handle/1957/10574

The Government, Decree No.42/2009/ND-CP, “About Urban Classification” Hanoi, May, 2009.

The National Assembly of Vietnam, No.16/2003/QH11. (2003). "Law of construction”, Hanoi, November, 26, 2003.

The National Assembly of Vietnam, No.30/2009/QH12. (2009). "Law on urban planning”, Hanoi, June, 17, 2009.

The Prime Minister, No589/QD-TTg. (2008). Decision "Approving the master plan on construction of the HO CHI MINH City Region up to 2020 with a vision toward 2050", Hanoi, May, 20,2008.

The prime Minister, No.1581/QD-TTg. (2008). Decision "Approving the master plan on construction of the Mekong River Delta region up to 2020 with a vision toward 2050", Hanoi, October, 09, 2008.

The Prime Minister, No.445/QD-TTg. (2009). Decision "Approving the overall plan orientation adjustment on Vietnamese urban system up to 2025 with a vision toward 2050", Hanoi, April, 07, 2009.

The Prime Minister, No.939/QD-TTg. (2012). Decision "Approving the overall plan on socio-economic development of the Mekong River Delta till 2020", Hanoi, July, 19, 2012.

UN \& IMF. (2013). Projections for Vietnam, population current growth trend and GDP growth forecast. Retrieved from http://www.imf.org/external/pubs/ft/weo/2013/01/weodata/weoselser.aspx?c=582\&t=1\#sNGDP_RPCH

Zhang, C., \& Wang, J. (2012). Village construction under China's rapid urbanization: The role and Strategy of planning in rural areas. World Academy of Science Engineering and Technology, 71, 166-168. Retrieved from $\mathrm{http}: / /$ waset.org/publications/9104

\section{Copyrights}

Copyright for this article is retained by the author(s), with first publication rights granted to the journal.

This is an open-access article distributed under the terms and conditions of the Creative Commons Attribution license (http://creativecommons.org/licenses/by/3.0/). 